DOI https://doi.org/10.18551/rjoas.2018-08.54

\title{
SIMULATION OF CLIMATE CHANGE IMPACT OF SOIL MOISTURE AVAILABILITY IN THE DRY LAND CORN FIELDS OF SUMBAWA REGENCY, NUSA TENGGARA BARAT PROVINCE
}

\author{
Ayu leke Wulan* \\ Doctoral Program, Faculty of Agriculture, University of Brawijaya, Indonesia \& \\ Faculty of Agriculture, University of Samawa, Indonesia \\ Prijono Sugeng, Soemarno \\ Department of Soil Sciences, Faculty of Agriculture, University of Brawijaya, Indonesia
}

\author{
Sebayang Husni Thamrin \\ Department of Agronomy, Faculty of Agriculture, University of Brawijaya, Indonesia
}

*E-mail: iekewulanayu002@gmail.com

\begin{abstract}
Climate change has great impact on the availability of soil moisture for the production of food crops in the drylands. Objective of the research was to study climate change simulations on the availability of soil moisture in dry land in Unter Iwes District, Sumbawa Regency, West Nusa Tenggara Province. The method used for water balance calculations was ThornthwaiteMather. Evapotranspiration calculations use the Penman Monteith model on the CROPWAT 8.0 model. The level of groundwater availability was obtained by analyzing groundwater content (KAT) data on the value of field capacity and permanent wilting point on dry land. The results revealed that changes in temperature and rainfall are factors that affect the water balance. The surplus occurred in January to March and the deficit occurred in April to November. The highest water-surplus was $244,2 \mathrm{~mm} \mathrm{~m}^{-1}$ in the Pelat Village and the lowest in Pungka Village was $225.5 \mathrm{~mm} \mathrm{~m}^{-1}$. The highest deficit was $494.32 \mathrm{~mm} \mathrm{~m}^{-1}$ in Pungka Village and the lowest in Pelat Village was $475,59 \mathrm{~mm} \mathrm{~m}^{-1}$. Increasing temperature and decreasing rainfall impact on water availability, thus reducing the surplus period at the study site. The deficit period shift occured only in scenarios accompanied by $10 \%$ rainfall $(\mathrm{C} 1, \mathrm{C} 5$ and C9). Decreased soil moisture availability and high demand for crop water affect the potential for reduction. The potential of corn yield reduction in Pelat Village is highest at $20,7 \%\left(\mathrm{C} 9 \Delta \mathrm{T}+6^{\circ} \mathrm{C}\right.$ and $\left.\Delta \mathrm{CH}-10 \%\right)$.
\end{abstract}

\section{KEY WORDS}

Climate change, moisture availability, water requirement, drylands.

Climate change, leading to increased extreme climatic events and a serious impact on agricultural production and food security (Downing, 1993; Lennon, 2015; Ochieng, Sendi and Mathenge, 2016; Ali and Erenstein, 2017). Climate change can be identified by changes in average values and variability in climatic elements, lasting for a long period of time (IPCC, 2013). Increased variability in rainfall from the atmosphere with rising temperatures has the potential to intensify soil moisture deficits, affect the quantity of crop production and the productivity of crops that have short life cycles, and the resilience of agro-ecosystems in the future (Valverde et al., 2014; Saadi et al., 2015).

The most extreme climatic events that affect agricultural sector in Indonesia are the EI Niño events that are dominated by decreasing rainfall and causing drought effects. IPCC (2014) shows that the earth's surface temperature has increased by $0,85^{\circ} \mathrm{C}\left(0,65-1,06^{\circ} \mathrm{C}\right)$ during the period 1880-2012, and the Indonesian region experienced a temperature increase of $0,8^{\circ} / 100$ years (Bappenas, 2014). El Niño events increase the chances of crop failure in the dry seasons due to plants experiencing water shortages. Lassa (2012) reported damage to 3.44 million ha of various types of crop failure due to the 7500 occurrences of natural 
disasters from 1970-2010. There is a close relationship between climate change and agricultural production (Winarto et al., 2013). Boer et al. (2014) stated that the increase of $1^{\circ} \mathrm{C}$ of Nino index in August caused the decline of rice production in the period of JanuaryApril next year by $10-20 \%$ in Java Island and more than $20 \%$ in South Sulawesi Province. Results of study by Surmaini et al. (2015) showed that rice drought was broader in El Niño events during 1991, 1994, 2002 and 2004. The average loss of rice production due to drought in the May-October period was 1,3 million tons. Effects of water stress and drought on plant growth and decrease in rice yield were also reported by other researchers (Boonjung and Fukai, 1996; Mostajeran and Rahimi-Eichi, 2009; Wu, Guan and Shi, 2011; Singh et al., 2012; Palanog et al ., 2014; Pandey and Shukla, 2015).

Water resources are the main inputs for agricultural development in any areas (Patanè et al., 2011; Sultana et al., 2017). Reduced availability of water due to changes in temperature and precipitation can disrupt the sustainability of agricultural production (Huntington, 2010). Evaluation of the limited availability of water in dry agricultural land is essential, in relation to the impacts of climate change and its effects on global food production. Both of these provide the basis for efficient irrigation scheduling and optimal allocation of water resources (Perea et al., 2016; Wang et al., 2016). Potential water resources in the form of groundwater storage are available indispensable in the framework of water management, especially the development of food crops (such as maize) in dry climates (Baier, 1969; Hunt et al., 2009; Zhao, Liu and Zhang, 2010; Ayu et al., 2013a; Akuraju et al., 2017).

Water availability can be analyzed based on soil characteristics and meteorological aspects (Zangiabadi et al., 2017). The availability of meteorological water is the availability of water that basically comes from rainwater. Rainfall data contribute to characterizing water availability for agricultural planning and management (Franciane, et al., 2018). The availability of water resources is strongly influenced by climatic conditions, topography, soil type, land cover and geological structure (Hartanto, 2017). The availability of meteorological water can be shown in the water balance chart. The water balance is a quantitative interpretation of the hydrological cycle that can be achieved through a general equation, describing the amount of in-flow water, available water, and water coming out of the system during a certain period (Brisson, 1998; Jenifa et al., 2010, Hadisusanto, 2010). Water balance is the basis for managing climate, soil and plants which is very useful for planning and developing agricultural production (Sujalu et al., 2014). The main components of soil water balance in agricultural land are rainfall, surface runoff, evaporation, transpiration, water exchange between root zones, seasonal variations of the water storage (Akuraju et al., 2017), and lateral seepage of soil water (Zhao and Zhao, 2014 ). The difference between precipitation and evapotranspiration in a catchment area is water reserves and can be utilized on the land (Soemarno, 2011). The correlation between water inflow, water expenditure and changes in soil water storage during a certain period (Sukerta et al., 2013), can be used to identify water sources and water use during this time period (Moghadas, 2009).

Water balance can be used to determine dynamics of water content in soil (Ayu et al., $2017^{\mathrm{b}}$ ). Quantification of water balance components is very helpful for understanding and analyzing the availability of water resources (Nzoiwu et al., 2017), extreme hydrological potentials such as floods and droughts, and interactions between soil and atmospheric surfaces, water resource efficiency (Qu et al., 2016). Thornthwaite and Mather (1957) is an approach used to determine the level of water availability, planting season and harvest potential. Thornthwaite-Mather Water Balance (TMWB) is a comprehensive water balance model for rooting environments (Dingman, 2002), one approach that can be used to predict the dynamics of soil water content for plant growth, so that it can calculate the amount of plant water demand, especially in the period critical where soil water levels are very low (Djufry, 2012), and future hydrological conditions (Huisman et al., 2009). Results of water balance simulation research by Ayu et al. $\left(2013^{c}\right)$ using the Thornthwaite-Mather model indicates a water surplus and water deficit at the study site. Tufaila et al. (2017) found water balance with surplus rainfall for three months, and water deficit for nine months. Results of 
Madarwilis et al. (2011) explained that the condition of soil moisture is always at the water limit available to plants, even though the water balance experiences a deficit, both under normal conditions, dry and wet conditions.

This research was conducted to determine the soil moisture availability using the water balance and climate change simulation in the drylands area of Unter-Iwes Subdistrict.

\section{METHODS OF RESEARCH}

The study was conducted in Unter Iwes Sub-district, Sumbawa District, West Nusa Tenggara Province (NTB), and Indonesia from March 2015-December 2017. Geographically, it is in position $8^{\circ} 32.5,5$ 'LS to $8^{\circ} 32.315^{\prime}$ LS and $117^{\circ} 24.51,8$ 'BT to $117^{\circ} 26.312^{\prime}$ BT. The data used in the research is meteorological data for the period of 2004-2016 from BMKG data of Sumbawa Regency. Research was conducted in two villages, Pelat Village and Pungka Village, based on dryland food crop agriculture and soil texture (Table 1). Research locations were selected based on the completeness of soil and meteorological informations and data (Figure 1).

Table 1 - Research location

\begin{tabular}{lll}
\hline Location & Cropping areas $(\mathrm{Ha})$ & Soil type \\
\hline $\begin{array}{l}\text { Pungka village } \\
\text { Pelat village }\end{array}$ & 133 & $\begin{array}{l}\text { Greyish-brown alluvial soil } \\
\text { Complex of Brown Mediterranean soil and Reddish- } \\
\text { brown Mediterranean soil }\end{array}$ \\
\hline
\end{tabular}

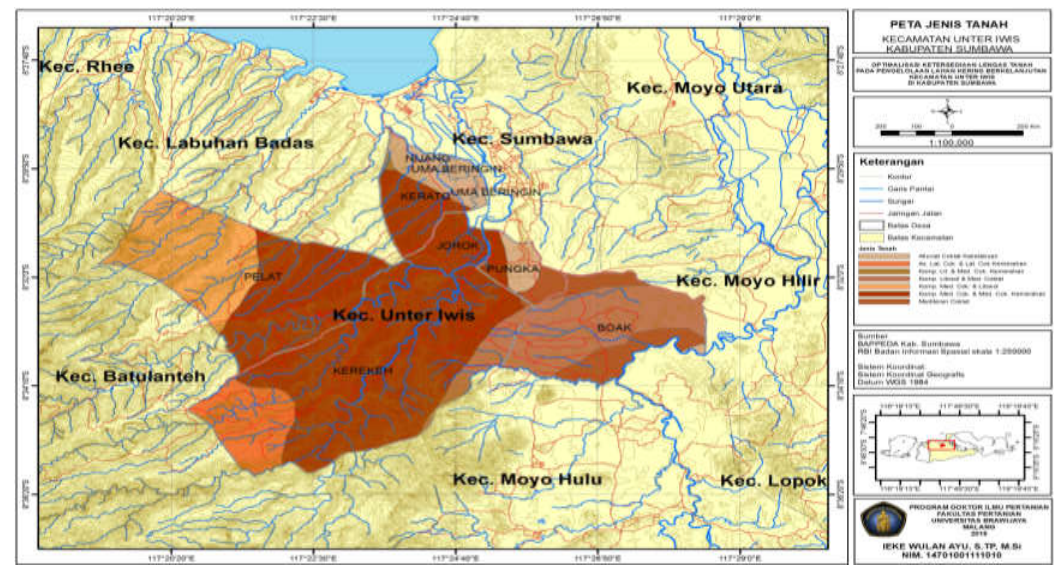

Figure 1 - Soil types in the research location

Water balance calculations are performed using the Thornthwaite-Mather method (regional water balance) (Thornthwaite \& Mather, 1957) and CROPWAT 8.0 model (water balance) (FAO, . Data for regional water balance input is rainfall calculated using the "USDA soil conservation service method" method. Estimates of evapotranspiration were analyzed using FAO-Penman Monteith on the Cropwat 8.0 model and the maximum soil capacity to retain water. The output of water balance is in the form of ground water deposits, surplus and deficit every month. Whereas CROPWAT 8.0 requires data on climate data input (maximum and minimum temperature, humidity, wind speed, and solar radiation), plant data, and soil data (water retention capacity, infiltration, and initial depletion). The capacity to hold water is converted into a thick form of water $\left(\mathrm{mm} \mathrm{m}^{-1}\right)$. The analysis of crop water demand (ETc) was done by comparing the value of AT with ETc calculated by equation 1 in each scenario of climate change (Table 2). The simulation of climate change impacts is based on global climate data for 2016, 2046, 2076, and 2106 using scenarios of temperature increase $(\Delta \mathrm{T})$ and rainfall change $(\Delta \mathrm{CH})$ (Table 3$)$.

ETc is defined as the amount of water lost in each plant growth phase $(\mathrm{Kc})$ through evapotranspiration (ETo). If $A T>E T c$, then the water requirement is fulfilled but if $A T<E T c$ 
then the plant will lack water in its growth phase. ETc has different values because it refers to the climatic conditions of the region.

$$
E T c=K c \times E T o
$$

Table 2 - Soil texture and Water Holding Capacity of soil

\begin{tabular}{llll}
\hline Location & Soil Texture & Water holding capacity $\left(\mathrm{mm} \mathrm{m}^{-1}\right)$ & \\
\hline & & Field moisture capacity & Available water \\
\hline Pungka village & Clay (Heavy soil) & 1.420 & 310 \\
Pelat village & Loam (Medium soil) & 1.180 & 770 \\
\hline
\end{tabular}

Table 3 - Scenario of climate change

\begin{tabular}{llll}
\hline Scenario & Year & Year $\Delta \mathrm{T}\left({ }^{\circ} \mathrm{C}\right)$ & $\Delta \mathrm{CH}(\%)$ \\
\hline C0 & Actual (2004-2016) & 0 & 0 \\
$\mathrm{C} 1$ & 2046 & 2 & -10 \\
$\mathrm{C} 2$ & 2046 & 2 & -5 \\
$\mathrm{C} 3$ & 2046 & 2 & 5 \\
$\mathrm{C} 4$ & 2046 & 2 & 10 \\
$\mathrm{C} 5$ & 2076 & 4 & -10 \\
$\mathrm{C} 6$ & 2076 & 4 & -5 \\
$\mathrm{C} 7$ & 2076 & 4 & 5 \\
$\mathrm{C} 8$ & 2076 & 4 & 10 \\
$\mathrm{C} 9$ & 2106 & 6 & -10 \\
$\mathrm{C} 10$ & 2106 & 6 & -5 \\
$\mathrm{C} 11$ & 2106 & 6 & 5 \\
$\mathrm{C} 12$ & 2106 & 6 & 10 \\
\hline
\end{tabular}

These calculations are used in general to estimate the plant's water requirements in optimal management and environmental conditions. But in the calculation of actual evapotranspiration, the stress coefficient $(\mathrm{Ks})$ is involved because it is not always in optimal condition.

$$
\mathrm{ETa}=\mathrm{Ks} \times \mathrm{Etc}
$$

Where: Ks is a function of total water available (TAW), water is available without causing plant stress (RAW) and depletion in the root zone (Dr). Ks is $0-1$, if Ks value 1 indicates the absence of water stress so that ETa value is equal to ETc.

$$
\mathrm{Ks}=\frac{\mathrm{TAW}-\mathrm{Dr}}{\mathrm{TAW}-\mathrm{RAW}}=\frac{\mathrm{TAW}-\mathrm{Dr}}{(1-\mathrm{p}) \mathrm{TAW}}
$$

The response of plants to the condition of water shortage is indicated by the increasing potential of crop yield (Yes). Each plant has a different yield reduction factor (Ky) (Equation 4).

$$
\left(1-\frac{Y a}{Y m}\right)=K y\left(\frac{E T a}{E T c}\right)
$$

\section{RESULTS AND DISCUSSION}

Impacts of El Nino on the trend of temperature and rainfall. During the 2004-2016 timeframe, there has been an upward trend in temperature in Sumbawa Regency (Figure 1). The average air temperature increased by $1^{\circ} \mathrm{C}-2^{\circ} \mathrm{C}$ in the last three years compared to normal conditions. Further the heating of air affects the spatial and seasonal distribution of rain and quantity of rainfall (Xu et al., 2009; Reuter et al., 2013; Rana et al., 20914; Trenberth et al., 2014; Loo, Billa and Singh, 2015; Szwed, 2015; Leng, Tang and Rayburg, 2015). 


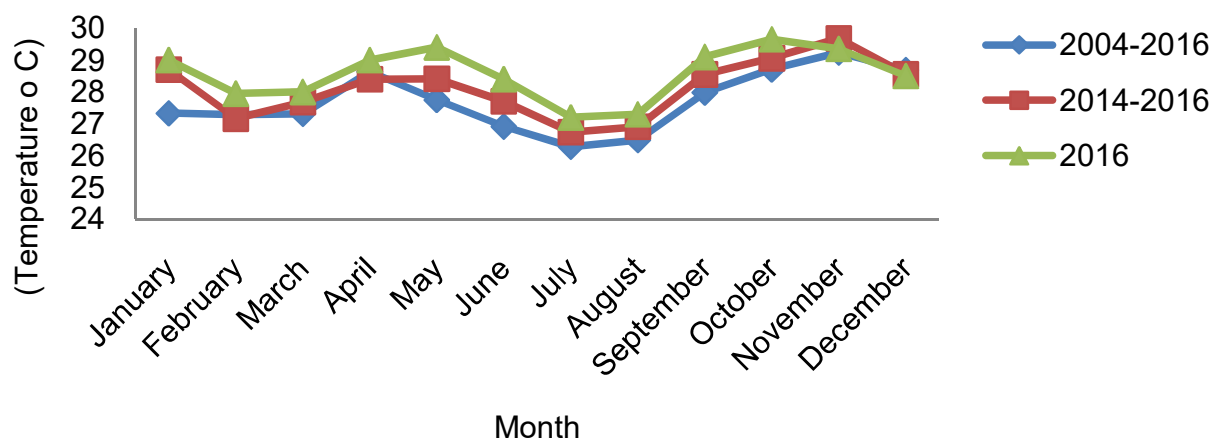

Figure 1 - Trend of temperature change in the Sumbawa Regency

Results showed that overall average rain fall in Sumbawa regency has low number in the period of 2004-2016 (13 years), 2014-2016 (three years), and 2016 (last year). In the period of 2004-2016, the average rainfall in Sumbawa Regency was $1,296 \mathrm{~mm}^{2}$ year ${ }^{-1}$ with effective rainfall that is $911.5 \mathrm{~mm}_{\text {year }}{ }^{-1}$. Very low annual rainfall of less than $2,000-<1,000$ $\mathrm{mm}$ year $^{-1}$, with 7-8 months dry months characteristic of dry climate dry land in the West Nusa Tenggara Province (Las et al. 2014).

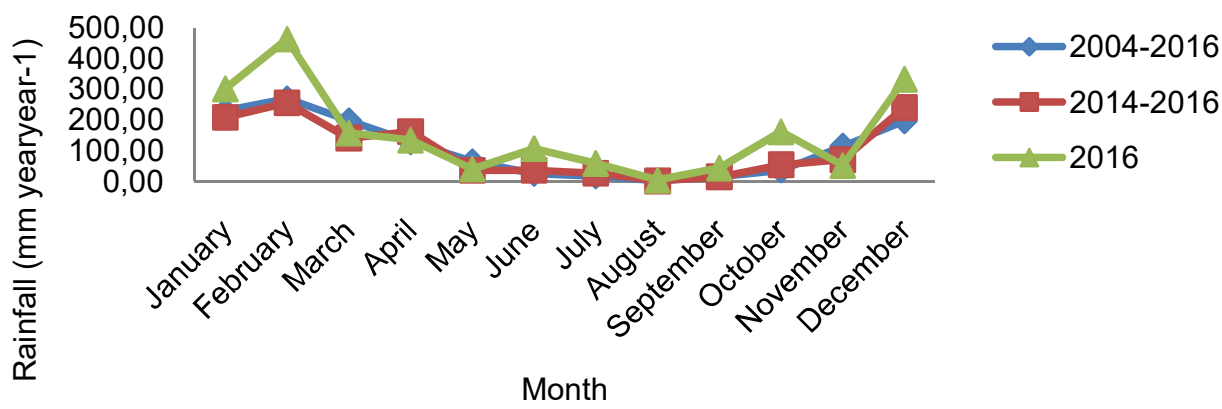

Figure 2 - Trend of rainfall change in the Sumbawa Regency

During the period 2004-2016, rainfall fluctuations were marked by the up and downs of precipitation and the shifting of months without rain. Low rainfall tendency occurs from May to September, and August is the peak of low rainfall. Rainfall tends to increase in October, and is the month of transition from the dry season to the rainy season. In November most of the research area entered the rainy season, and the accumulation of rainfall increased from December to March. The ups and downs of rain show the difference between rainy and dry seasons. In April is the end of the rainy season, so the accumulation of rainfall is reduced compared to the previous month, due to enter the dry season. Increased rainfall starts from November to February. The rainy season lasts from November to March, and summer runs from May to September, while October is the month of transition (Loo et al., 2015).

The period of 2010 is the year with the highest rainfall, which is $1818,4 \mathrm{~mm}_{\text {year }}{ }^{-1}$, and the period of 2004 is the period with the lowest average rainfall is $820,6 \mathrm{~mm}$ year ${ }^{-1}$, with three months without rain in July, August, and September. The month without rain occurred in 2011-2012, namely from June to August which was marked by the decrease in the average rainfall intensity from $1631,1 \mathrm{~mm}$ year $^{-1}$ in 2011 to $1303,8 \mathrm{~mm}_{\text {year }}{ }^{-1}$ in $2012 \mathrm{The}^{2}$ shifting months without the rainfall that occurred in 2004 and 2011 indicates that a month without rain occurs early with a longer time of 4 months. In the 2014-2016 period (the last three years) shows the average amount of rainfall has increased, namely $907 \mathrm{~mm}$ in the first year (2014) to $1,860 \mathrm{~mm}$ in the first year (2016). High rainfall intensity in 2016, marked by rainfall throughout the year, with low rainfall occurring in August, and the incidence of high rainfall intensity, in 2016 occurred in 2010 in the period 2004-2016. Higher rainfall will affect higher surface runoff and impact on the decrease in groundwater filling rate (Trenberth, 
2011). The rise and fall of rainfall in an area is the impact of global temperature changes (IPCC, 2014; Suryadi et al., 2017), which has implications for changes in climatic elements such as rainfall, temperature and other climatic elements (Bhatt and Mall, 2015). The EL Nino (2009) and La Nina (2010) phenomena have an impact on the distribution and value of rainfall intensity in Indonesian territory (Zubaidah, 2012). The decline in rice productivity in 2013 was caused by the El Nino phenomenon with a long dry season and continued until 2016 in Sumbawa Regency (BPS of Sumbawa Regency, 2016).

Changes in air temperature will affect rainfall. Reduced rainfall and increased temperatures will affect the availability of water through the mechanism of evapotranspiration. The results showed that the evapotranspiration value fluctuated around 96, $1 \mathrm{~mm}$. The main climate variables affecting ETo in Sumbawa Disctirct are temperature, wind speed, and solar radiation (Ayu et al., 2018 ${ }^{\mathrm{d}}$ ).

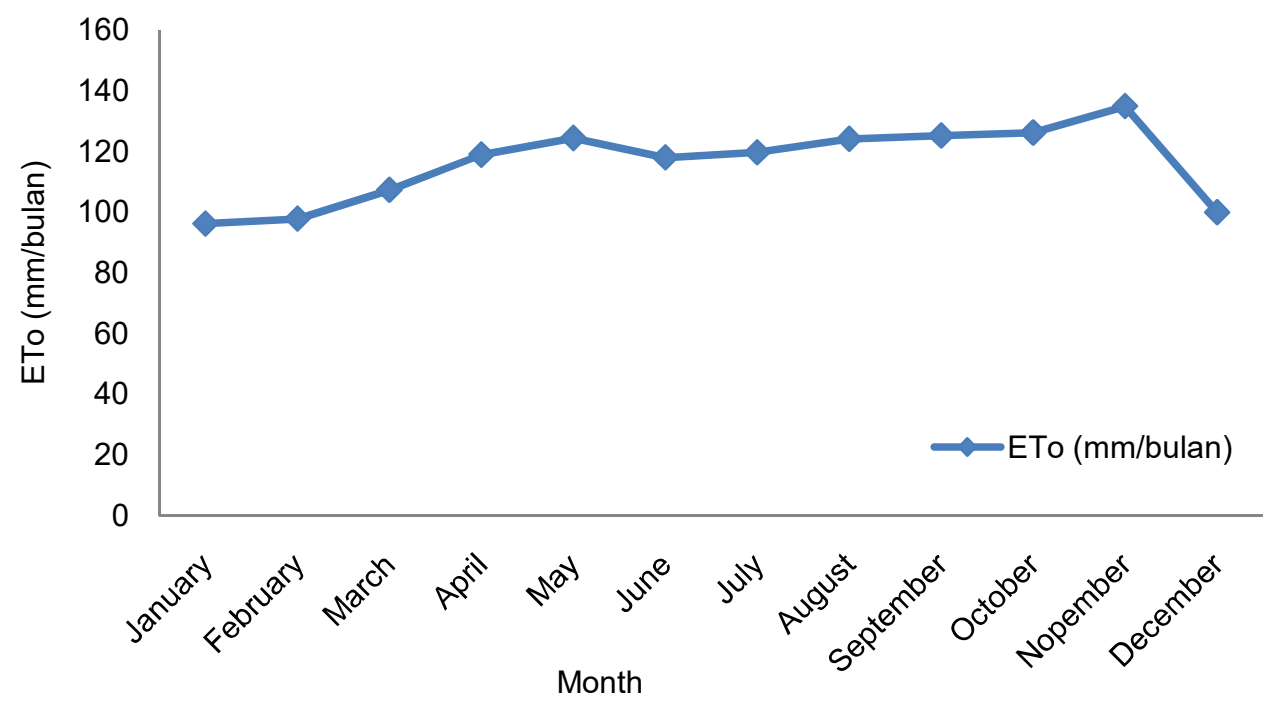

Figure 3 - Evapotranspiration values estimated by the Penman-Monteith methode

Water balance of the Region. Rainfall and evapotranspiration can provide important information about the estimated amount of water that can be obtained to determine the period of surplus or water deficit in the field (Ayu et al., $2013^{\mathrm{c}}$ ). Calculations of the Thornthwaite-Mather water balance produce the value of surplus water and deficit and water stored in the soil (ST). Changes in temperature and precipitation affect the amount of water (Machiwal et al., 2016; Ghanem et al., 2011; Muchuru et al., 2016). The results of water balance analysis in Pungka Village and Pelat Village showed that the surplus period occurred for 3 months ie in January-March, and deficit period occurred during 8 months ie in April-November (Figure 4).

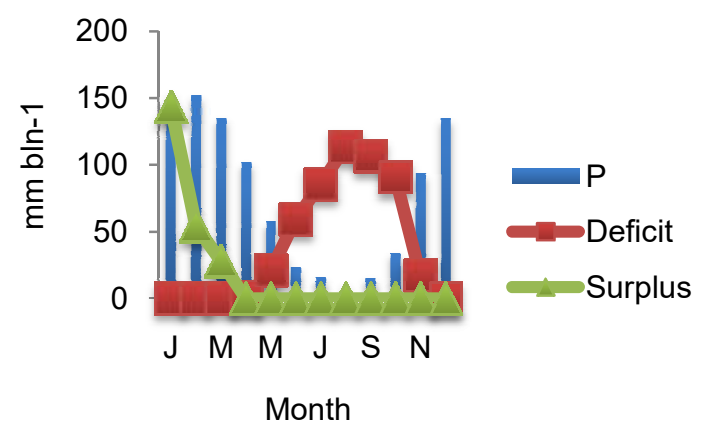

a. Water balance in the Pungka village

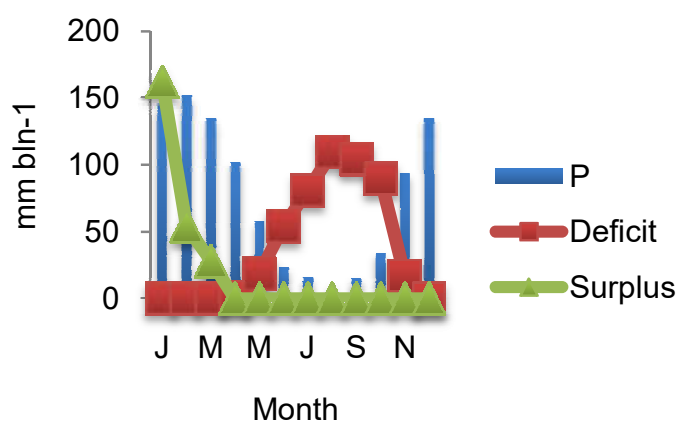

b. Water balance in the Pelat village

Figure 4 - Water balance in the Research locations 
Pelat Village is a village that has a surplus value of $244,2 \mathrm{~mm}^{-1} \mathrm{year}^{-1}$ and a deficit of $475,59 \mathrm{~mm}$ year $^{-1}$ high compared to Pungka Village with a surplus value $\left(225,5 \mathrm{~mm}\right.$ year $\left.^{-1}\right)$ and deficit $\left(494,32 \mathrm{~mm}_{\text {year }}{ }^{-1}\right)$. The highest surplus in Desa Pelat of $162.0 \mathrm{~mm}_{\text {year }}{ }^{-1}$ and Desa Pungka for $143,2 \mathrm{~mm}^{\text {year }}{ }^{-1}$ occurred in January. The lowest surplus in Pelat and Pungka Village was $27,9 \mathrm{~mm}$ year $^{-1}$ in March. The high surplus value shows a low water storage (ST), the analysis results show that the ST value in Pungka Village is $761,32 \mathrm{~mm}$ year ${ }^{-1}$ with STo value, which is $130 \mathrm{~cm}$ lower than ST in Desa Pelat which reaches 898,934 $\mathrm{mm}$ year $^{-1}$ with STo value of $150 \mathrm{~cm}$. The high deficit value compared to surplus is influenced by climate in Sumbawa Regency which is classified as dry with low rainfall. The deficit occurs as a result of changes in water reserves that are used for evapotranspiration and the absence of rainwater supply. The highest deficit in Desa Pelat was 109,62 mm year1 , and Pungka Village $113,33 \mathrm{~mm}$ year ${ }^{-1}$ occurred in August. The high deficit value of Pungka Village is influenced by the amount of soil moisture retained (STo) equal to the capacity of soil in storing water (WHC), and the smaller the STo value indicates the greater the drought index. The results of the research Faqih et al. (2016) explains that the projected annual rainfall changes in the future will decrease rainfall in the southern parts of Sumatra and Kalimantan, most of Java, Bali and Nusa Tenggara.

Water deficit in research area is influenced by physical properties of soil, one of which is texture. The results showed that the soil texture in Pungka village tended to be clayy and had a high ability to retain water compared to clay textured soil in Desa Pelat. Soil texture is one of the soil physics characteristics that affect the availability of soil moisture (Adiputra et al., 2016), one of the important factors affecting soil capacity to retain water as well as various physical and chemical properties of other soils (Arsyad, 2010).

Impacts of climate change on the watrer balance. Changes in temperature and decreased availability of rainfall affect water availability. The projected impacts of climate change on the availability of soil moisture by setting scenarios in the study (2004-2016, 2046, 2076, and 2106) show that the more extreme scenarios used, the greater the increase in water supply deficits. Climate change will affect the precipitation, evapotranspiration and water balance (Garner et al., 2017, Kirby et al., 2016).

The results show a comparison between conditions 0 (actual) and other scenarios (Table 4). The difference from the temperature increase of $2-6^{\circ} \mathrm{C}$ caused the increase of evapotranspiration of $3,91-4,24 \%$ so that it impacted the decreasing of surplus period at study location. The deficit period shift occurs only in scenarios accompanied by $10 \%$ rainfall (C1, C5, and C9) at both locations. Shifts occur in May and October which are transitional periods. Temperature rise causes higher evapotranspiration, and will increase the demand for water for irrigation (Wang et al., 2012).

Table 4 - Impacts of climate change on the water Surplus and water Deficit

\begin{tabular}{|c|c|c|c|c|c|c|c|c|}
\hline \multirow{3}{*}{ Scenario } & \multicolumn{4}{|c|}{ Pungka village } & \multicolumn{4}{|c|}{ Pelat village } \\
\hline & \multicolumn{2}{|c|}{ Deficit } & \multicolumn{2}{|c|}{ Surplus } & \multicolumn{2}{|c|}{ Deficit } & \multicolumn{2}{|c|}{ Surplus } \\
\hline & $\mathrm{mm}$ & months & $\mathrm{mm}$ & months & $\mathrm{mm}$ & months & $\mathrm{mm}$ & months \\
\hline $\mathrm{CO}$ & 494,32 & 8 & 225,5 & 3 & 475,59 & 8 & 244,2 & 3 \\
\hline C1 & 566,17 & 8 & 199,1 & 2 & 547,00 & 8 & 210,3 & 2 \\
\hline $\mathrm{C} 2$ & 551,74 & 8 & 211,2 & 3 & 532,65 & 8 & 230,2 & 3 \\
\hline C3 & 523,11 & 8 & 220,3 & 3 & 504,19 & 8 & 239,2 & 3 \\
\hline C4 & 509,21 & 8 & 223,7 & 3 & 490,38 & 8 & 242,5 & 3 \\
\hline C5 & 612,03 & 8 & 187,0 & 2 & 597,47 & 8 & 201,6 & 2 \\
\hline $\mathrm{C} 6$ & 597,58 & 8 & 202,1 & 3 & 578,28 & 8 & 221,4 & 3 \\
\hline $\mathrm{C} 7$ & 568,90 & 8 & 211,2 & 3 & 549,73 & 8 & 230,4 & 3 \\
\hline $\mathrm{C} 8$ & 523,11 & 8 & 220,3 & 3 & 504,19 & 8 & 239,2 & 3 \\
\hline C9 & 647,40 & 8 & 184,3 & 2 & 627,91 & 8 & 203,8 & 2 \\
\hline C10 & 632,94 & 8 & 194,4 & 3 & 613,50 & 8 & 213,9 & 3 \\
\hline C11 & 604,23 & 8 & 203,6 & 3 & 584,90 & 8 & 223,0 & 3 \\
\hline C12 & 590,28 & 8 & 187,6 & 3 & 571,01 & 8 & 206,9 & 3 \\
\hline
\end{tabular}

Changes in the duration of the surplus months cause groundwater savings to fluctuate, which tends to decrease. Overall ST value decreased compared to actual condition in all 
climate change scenarios except in scenario $\mathrm{C} 4\left(\Delta \mathrm{T}=+2^{\circ} \mathrm{C} ; \Delta \mathrm{CH}=+10 \%\right)$ in Pungka Village which increased by $761,699 \mathrm{~mm}$ year ${ }^{-1}$ from actual condition that is $761,315 \mathrm{~mm}$ year 1. This is related to the increase in rainfall that goes further beyond potential evapotranspiration, and soil texture conditions in Pungka Village, which is dominated by clay fraction, so the ability to hold water is higher than in Pelat Village. ST decreases in all sites ranged from $724,521 \mathrm{~mm}_{\text {year }}{ }^{-1}-898,473 \mathrm{~mm}_{\text {year }}{ }^{-1}$ compared to actual conditions. The highest ST drop in all areas occurred in scenario $C 9\left(\Delta \mathrm{T}=+6^{\circ} \mathrm{C} ; \Delta \mathrm{CH}=-10 \%\right)$ of 696,196 for Pungka Village and $821,14 \mathrm{~mm}_{\text {year }}{ }^{-1}$ for Pelat Village.

Effects of climate change on the maize water requirement. Simulation is done in areas experiencing a decrease in rainfall, there is the possibility of increased opportunities for drought. Conversely, in areas that tend to increase rainfall, it is likely that there will be frequencies and intensity of extreme rainfall. Climate simulation is one way to know climate projection ahead by considering various things that affect climate conditions.

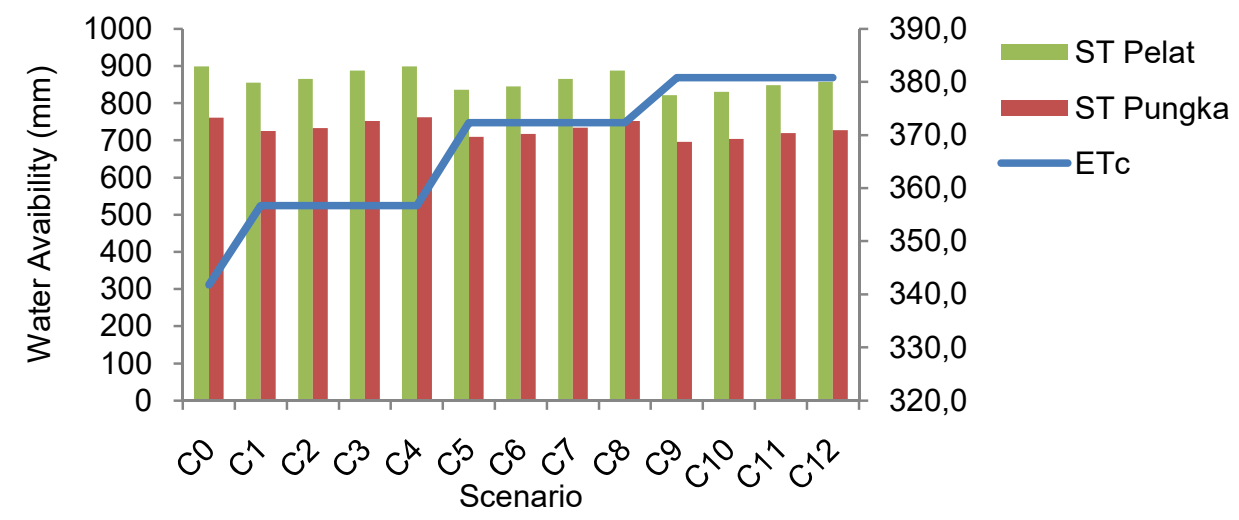

Figure $4-$ Water availability in the location of Pungka and Pelat villages

The result of climate projection analysis predicts that in 2106 an increase in evapotranspiration and demand for crop water due to global warming will reduce water supply surplus and will significantly increase demand for irrigation water during periods of plant growth in the dry season. Selection of the right planting time according to the condition of water availability can avoid from the high yield decline (Ayu et al., 2013 ${ }^{\mathrm{e}}$ ). Increasing the efficiency of water use of maize crops will effectively reduce total water demand and improve the resilience of agricultural systems to climate change (Garcia, Guerra and Hoogenboom, 2009; Hernández et al., 2015; Greaves and Wang, 2017; Mo et al., 2017) . Changes in the value of evapotranspiration, driven by variability in temperature, sun, wind, vapor pressure (Ayu et al., 2018), rainfall dynamics play an important role in the variation of a region's climate balance (Prăvălie et al., 2014; Zhao and Zhao, 2014). The results show that the impacts of climate change have been seen with increasing water demand due to rising temperatures in the C1-C12 scenario.

Increasing water demand is increasing especially at the increase of temperature accompanied by decreasing of rainfall. Climate change affects changes in patterns and intensity of rainfall (Bates et al., 2008). Tables 5 and 6 show that an increase in temperature of $2^{\circ}-6^{\circ} \mathrm{C}$ increases the crop water requirement from actual conditions, as indicated by higher ETc and ETa values. Under conditions below the maximum soil water deficit, plants have already begun the difficulty in absorbing water. In such circumstances some of the plant stomata close down, resulting in an actual evapotranspiration of magnitude under potential evapotranspiration. If this condition often occurs, crop production can decrease (Wahjunie et al., 2008). Djaman et al. (2018) argue that plant evapotranspiration (ETa) is an important parameter in hydrology, and plays a key role in designing and managing water in rainfed agriculture, which is estimated by indirect methods using reference to plant evapotranspiration (ETo) and crop coefficient.

The realization of cultivation done in dry months has a risk to crop yield. Increased water demand has an impact on water availability that is not sufficient for crop water 
requirements, especially when entering the dry month as indicated by the reduction of yields at two sites. Adequate available water for the growth and production of corn is $30 \%$ available water (maximum soil water deficit), the amount of water stored in the soil that can be immediately available to plants without stress, and for sweet corn above $50 \%$ (Allen et al., 1998; Shaxson and Barber, 2003).

Table 5 - Impacts of climate change on the soil water available and potential reduction of maize yield during the rainy season in the Pungka village

\begin{tabular}{|c|c|c|c|c|c|c|}
\hline \multirow[t]{4}{*}{ Scenario } & \multicolumn{3}{|c|}{ Planting date: $11^{\text {th }}$ November } & \multicolumn{3}{|c|}{ Planting date: 11th Maret } \\
\hline & \multicolumn{3}{|c|}{ Harvesting date: $28^{\text {th }}$ Februari } & \multicolumn{3}{|c|}{ Harvesting date: 6 th Juni } \\
\hline & \multicolumn{3}{|c|}{ Season: Rainy (wet) } & \multicolumn{3}{|c|}{ Season: Dry } \\
\hline & Etc $(\mathrm{mm})$ & ETa $(\mathrm{mm})$ & Crop yield reduction (\%) & Etc $(\mathrm{mm})$ & Eta $(\mathrm{mm})$ & Crop yield reduction (\%) \\
\hline C1 & 292,8 & 291,2 & 0,0 & 356,7 & 347,3 & 2,7 \\
\hline $\mathrm{C} 2$ & 292,8 & 291,2 & 0,0 & 356,7 & 349,9 & 1,8 \\
\hline C3 & 292,8 & 291,2 & 0,0 & 356,7 & 354,9 & 0,0 \\
\hline C4 & 292,8 & 291,2 & 0,0 & 356,7 & 354,9 & 0,0 \\
\hline C5 & 306,4 & 304,7 & 0,0 & 372,3 & 354,4 & 5,4 \\
\hline C6 & 306,4 & 304,7 & 0,0 & 372,3 & 357,2 & 4,5 \\
\hline $\mathrm{C} 7$ & 306,4 & 304,7 & 0,0 & 372,3 & 365,4 & 1,7 \\
\hline $\mathrm{C} 8$ & 306,4 & 304,7 & 0,0 & 372,3 & 368,7 & 0,6 \\
\hline C9 & 309,5 & 307,8 & 0,0 & 380,8 & 359,0 & 6,6 \\
\hline C10 & 309,5 & 307,8 & 0,0 & 380,8 & 361,9 & 5,6 \\
\hline C11 & 309,5 & 307,8 & 0,0 & 380,8 & 370,6 & 2,7 \\
\hline C12 & 309,5 & 307,8 & 0,0 & 380,8 & 374,3 & 1,5 \\
\hline
\end{tabular}

Note: $E T c=$ Crop Evapotranspiration; $E T a=$ actual Evapotranspiration; $R P=$ Reduction of crop yield, Soil type = Clay soil (heavy-soil).

Table 6 - Impacts of climate change on the soil water available and potential reduction of maize yield during the rainy season in the Pelat village

\begin{tabular}{|c|c|c|c|c|c|c|}
\hline \multicolumn{4}{|c|}{ Planting date: 11th November } & \multicolumn{3}{|c|}{ Planting date: 11th March } \\
\hline \multicolumn{4}{|c|}{ Harvesting date: 28th February } & \multicolumn{3}{|c|}{ Harvesting date: $6^{\text {th }}$ June } \\
\hline Season: & ainy (wet) & & & Season: [ & & \\
\hline Skenario & Etc $(\mathrm{mm})$ & ETa $(\mathrm{mm})$ & Crop yield reduction (\%) & Etc $(\mathrm{mm})$ & Eta $(\mathrm{mm})$ & Crop yield reduction (\%) \\
\hline C1 & 292,8 & 291,2 & 0,0 & 356,7 & 354,9 & 16,4 \\
\hline $\mathrm{C} 2$ & 292,8 & 291,2 & 0,0 & 356,7 & 311,8 & 15,2 \\
\hline C3 & 292,8 & 291,2 & 0,0 & 356,7 & 322,3 & 11,5 \\
\hline C4 & 292,8 & 291,2 & 0,0 & 356,7 & 327,3 & 9,70 \\
\hline C5 & 306,4 & 304,7 & 0,0 & 372,3 & 312,7 & 19,5 \\
\hline C6 & 306,4 & 304,7 & 0,0 & 372,3 & 316,3 & 18,3 \\
\hline $\mathrm{C} 7$ & 306,4 & 304,7 & 0,0 & 372,3 & 327,0 & 14,7 \\
\hline C8 & 306,4 & 304,7 & 0,0 & 372,3 & 332,2 & 12,9 \\
\hline $\mathrm{C} 9$ & 309,5 & 307,8 & 0,0 & 380,8 & 316,3 & 20,7 \\
\hline C10 & 309,5 & 307,8 & 0,0 & 380,8 & 319,8 & 19,5 \\
\hline C11 & 309,5 & 307,8 & 0,0 & 380,8 & 330,6 & 15,9 \\
\hline C12 & 309,5 & 307,8 & 0,0 & 380,8 & 335,9 & 14,2 \\
\hline
\end{tabular}

Note: $E T c=$ Crop Evapotranspiration; $E T a=$ actual Evapotranspiration; $R P=$ Reduction of crop yield, Soil type = Loam (Medium-soil).

The reduction of the dry season results in the Plates location was a high reduction in yield compared to the reduction of the Pungka location. Different conditions are shown by the scenario of a temperature increase of $2^{\circ} \mathrm{C}$ with $5-10 \%$ rainfall in Pungka Village which has clay textured soil showing a reduction in yield of $0,0 \%$, compared to the same scenario in Desa Pelat with clay textured soil showing a reduction in yield of $11,5-9,70 \%$. Increased temperatures of $4{ }^{\circ} \mathrm{C}-6{ }^{\circ} \mathrm{C}$ along with a decrease in rainfall of $5-10 \%$ can cause water availability during dry months to be deficit, and can not be met by high rainfall. Large rains can cause water movement only through the macro pores without penetrating the soil matrix (Sugita et al., 2004). The influence of rain on the movement and distribution of water in the soil is also very dependent on soil pore characteristics in relation to water content before rain and the rate of soil infiltration (Shipitalo et al., 1990). Infiltration of the study area was 
influenced by soil type, soil organic matter, porosity, bulk density, specific gravity and initial soil moisture content (Ayu et al., 2013 ${ }^{f}$ ).

Climate change will have an impact on plant growth and the amount of water needed by plants to grow well (Ayu et al., 2013 ); Mehta et al., 2013; Saadi et al., 2015; Wang et al., 2016). The results of Ayu et al. $\left(2018^{\mathrm{e}}\right)$ explained that the realization of cultivation in May may increase the risk of crop yield reduction, caused by decreased rainfall during period of plant growth. Changes in crop water requirements (CWR) and the needs of crop irrigation under climate change conditions can provide a theoretical basis for the design of irrigation water conservation facilities and management of agricultural water resources (Zhou et al., 2017). In efforts to reduce or eliminate the impacts of climate change on crop production, Okonya et al. (2013) and Thuy et al. (2014) suggest crop diversification, harvest rotation, and application of production-enhancing technologies. Soil management using mulch can increase rainwater storage in the soil (Wanga et al., 2018) and the availability of soil moisture at a depth of $20-60 \mathrm{~cm}$, and increase plant growth and yield (Cook, Valdes and Lee, 2006; Chakraborty et al. 2008; Bana et al., 2013).

\section{CONCLUSION}

Low rainfall trends occur in May to September, and August is the peak of low rainfall. Water surplus in the Pelat village is a maximum of $244,2 \mathrm{~mm}_{\text {year }}{ }^{-1}$ and water deficit of $475.59 \mathrm{~mm}$ year $^{-1}$. Increasing the temperature of $2-6^{\circ} \mathrm{C}$ causes an increase in evapotranspiration of $3,9-4,24 \%$, thus impacting the reduced water surplus period at the study site. The shift in the period of water deficit only occurs in a scenario of $10 \%$ rain reduction $(\mathrm{C} 1, \mathrm{C} 5$, and $\mathrm{C} 9)$. A temperature increase of $4-6^{\circ} \mathrm{C}$ and is accompanied by a decrease in 5-10\% rainfall, resulting in water deficit during dry months, and not yet fulfilled despite high rainfall. Yield reduction of maize in the Pelat Village is highest of $20,7 \%$ in the scenario of $\mathrm{C} 9\left(\Delta \mathrm{T}+6^{\circ} \mathrm{C}\right.$ and $\left.\Delta \mathrm{CH}-10 \%\right)$.

\section{REFERENCES}

1. Adiputra., D.F Pramanta., I.W Ayu \& Z. Kusuma. 2016. Manajemen Lengas Tanah di Lahan Kering. Graduate Program, Fac. of Agriculture, Univ. of Brawijaya, MalangIndonesia.

2. Akuraju, V.R., D.Ryu, B.George, Y.. 2017. Seasonal and Inter-annual Variability of Soil Moisture Stress Function in Dryland Wheat Field, Australia. Agricultural and Forest Meteorology (232): 489-499.

3. Ali, A. \& O.Erenstein. 2017. Assessing farmer use of climate change adaptation practices and impacts on food security and poverty in Pakistan. Climate Risk Management, (16): 183-194.

4. Allen, R.G., L.S. Pereira, D. Raes, \& M. Smith. 1998. Crop EvapotranspirationGuidelines for Computing Crop Water Requirement-FAO Irrigation and Drainage Paper 56. FAO. Rome.

5. Arsyad, S. 2010. Konservasi Tanah \& Air. Bogor Agriculture University, Indonesia.

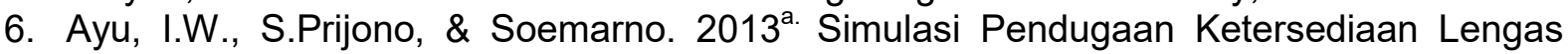
Tanah Lahan Kering Kecamatan Unter Iwes di Kabupaten Sumbawa. Tesis Program Pascasarjana Universitas Brawijaya. Malang.

7. Ayu, I.W., S.Prijono \& Soemarno. 2013 ${ }^{\mathrm{b}}$. Evaluation of Soil Moisture Availability in Root Zone: Case Study in Unter-Iwes Drylands, Sumbawa, Indonesia. International Journal of Ecosystem, 3(5): 115-123. DOI: 10.5923/j.ije.20130305.03.

8. Ayu, I.W., H.T.Sebayang, Soemarno \& S.Prijono. $2017^{\circ}$. Model Neraca Air Lahan untuk Mendukung Pola Tanam pada Pengelolaan Lahan Kering Berkelanjutan di Kabupaten Sumbawa, NTB. Prosiding Seminar Ilmiah Tahunan Lingkungan Hidup. Fakultas Teknologi Pertanian. Universitas Brawijaya. Malang. ISBN. 978-979-99002-6-5. 
9. Ayu, I.W., H.T.Sebayang, Soemarno \& S.Prijono . 2018 . Estimation of the Reference Evapotranspiration in Sumbawa District, West Nusa Tenggara, Indonesia. International Journal of Agriculture Innovations and Research, 6(4): xx. ISSN (Online) 2319-1473.

10. Ayu, I.W., H.T.Sebayang, Soemarno \& S.Prijono. 2018 ${ }^{e}$. Assessment of Rice Water Requirement by Using CROPWAT Model in Sumbawa Regency, West Nusa Tenggara, Indonesia. VEGETOS, 31(2): xx. DOI: 10.4172/2229-4473.1000409.

11. Ayu, I.W., S.Prijono \& Soemarno. 2013 ${ }^{\mathrm{f}}$. Assessment of Infiltration Rate under Different Drylands Types in Unter-Iwes Subdistrict Sumbawa Besar, Indonesia. Journal of Natural Sciences Research, 3(10): xx. ISSN 2224-3186 (Paper) ISSN 2225-0921 (Online)

12. Ayu, I.W., Prijono, S. \& Soemarno. $2013^{\mathrm{g}}$. Evaluasi Ketersediaan Air Tanah Lahan Kering di Kecamatan Unter Iwes, Sumbawa Besar. J-PAL, 4(1): xx. (in Indonesian).

13. Baier,W. 1969. Concepts of Soil Moisture Availability and Their Effect on Soil Moisture Estimates From A Meteorological Budget. Agricultural Meteorology, 6(3): 165-178.

14. Bana,S., S.Prijono, Ariffin \& Soemarno 2013. The Effect of Soil Management on the Availability of Soil Moisture and Maize Production in Drylan. International Journal of Agriculture and Forestry, 3(3): 77-85.

15. Bappenas, 2014. Rencana Aksi Nasional Adaptasi Perubahan Iklim (RAN API), Bappenas. Republik Indonesia.

16. Bates, B.C., Z.W.Kundzewicz, S.Wu and J.P.Palutikof. (eds) . 2008. Climate Change and Water. Technical Paper of the Intergovernmental Panel on Climate Change. Geneva: IPCC Secretariat.

17. Boer, R.A., Faqih \& R. Ariani. 2014. Relationship between Pacific and Indian Ocean Sea Surface Temperature Variability and Rice Production, Harvesting Area and Yield in Indonesia. Paper presented in EEPSEA conference on the Economics of Climate Change. 27-28 February, Siem Reap, Cambodia.

18. Boonjung,H. \& S.Fukai. 1996. Effects of Soil Water Deficit at Different Growth Stages on Rice Growth and Yield Under Upland Conditions. 1. Growth during drought. Field Crops Research, 48(1): 37-45.

19. Brisson, N. 1998. An Analytical Solution for The Estimation of The Critical Available Soil Water Fraction for a Single Layer Water Balance Model Under Growing Crops. Hydrology and Earth System Sciences, 2(2-3): 221-231.

20. Chakraborty, D., S.Nagarajan, P.Aggarwal, V.K.Gupta, R.K.Tomar, R.N.Garg, R.N.Sahoo, A.Sarkar, U.K.Chopra, K.S.S.Sarma, \& N.Kalra. 2008. Effect of Mulching on Soil and Plant Water Status: and the Growth and Yield of Wheat (Triticum aestivum L.) in a Semi-Arid Environment. Agric. Water Manage., 95: 1323-1334.

21. Cook,H.F., G.S.Valdes, \& H.C.Lee. 2006. Mulch Effects on Rainfall Interception, Soil Physical Characteristics and Temperature Under Zea mays L. Soil Till. Res. 91: 227235.

22. Dingman,S.L. 2002. Physical Hydrology. 2nd ed. New Jersey: Prentice Hall.

23. Diva-Bhatt \& R.K. Mall. 2015. Surface Water Resources, Climate Change and Simulation Modeling. Aquatic Procedia, 4: $730-738$.

24. Djaman,K., A.B.Balde, A.Sow, A.B.Muller, S.Irmak, M.K.N'Diaye, B.Manneh, Y.D.Moukoumbi, K.Futakuchi \& K.Saito. 2015. Evaluation of Sixteen Reference Evapotranspiration Methods Under Sahelian Conditions in The Senegal River Valley. J. Hydrol. Reg. Stud., 3: 139-159.

25. Djufry, F. 2015. Pemodelan Neraca Air Tanah untuk Pendugaan Surplus dan Defisit Air Untuk Pertumbuhan Tanaman Pangan di Kabupaten Merauke, Papua. Informatika Pertanian. 21 (1): 1-9. (in Indonesian).

26. Downing,T.E. 1993. The Effects of Climate Change on Agriculture and Food Security. Renewable Energy, 3(4-5): 491-497.

27. FAO. 2012. Database \& Software CROPWAT 8. Natural Resources and Environment Departemen. Available: http://www.fao.org. Accses 7-12-2017.

28. Faqih,A.R. Hidayat, S.D. Jatmiko \& Radini. 2016. Climate modeling and analysis for Indonesia 3rd national communication (TNC): Historical and climate and future climate 
scenarios in Indonesia. Final Report. Ministry of Environment and Forestry (MoEF). United National Development Programme (UNDP) and Bogor Agicultural University.

29. Franciane,L.R. de O.Louzada, A.C.Xavier, \& J.E.M. Pezzopane. 2018. Climatological Water Balance With Data Estimated By Tropical Rainfall Measuring Mission For The Doce River Basin. Engenharia Agrícola, Jaboticabal, 38(3): 376-386.

30. Garcia,A.G., L.C.Guerra, \& G.Hoogenboom. 2009. Water Use and Water Use Efficiency of Sweet Corn Under Different Weather Conditions and Soil Moisture Regimes. Agricultural Water Management, 96(10): 1369-1376.

31. Garner, G., D.M. Hannah \& G. Watts. 2017. Climate Change and Water in the UK: Recent Scientific Evidence for Past and Future Change. Progress in Physical Geography: Earth and Environment , 41(2): 154 - 170

32. Ghanem, A. 2011. Trends in Mean Seasonal and Annual Rainfall Amounts over Jordan. Hum. Soc. Sci., 38:1041-1049.

33. Greaves,G.E. \& Y.M.Wang. 2017. Effect of regulated deficit irrigation scheduling on water use of corn in southern Taiwan tropical environment. Agricultural Water Management, 188: 115-125.

34. Hadisusanto, N. 2010. Aplikasi Hidrologi. Jogja Mediautama Publ., Malang.

35. Hartanto,P. 2017. Perhitungan Neraca Air DAS Cidanau Menggunakan Metode Thornthwaite. Ris.Geo.Tam., 27(2): 213-225.

36. Hernández,M., L. Echarte, A.D.Maggiora, M.Cambareri, P.Barbieri \& D.Cerrudo. 2015. Maize Water Use Efficiency and Evapotranspiration Response To N Supply Under Contrasting Soil Water Availability. Field Crops Research, 178: 8-15.

37. Huisman,J.A., L.Breuer, H.Bormann, A.Bronstert, B.F.W.Croke, H.Frede \& T.Graft. 2009. Assessing the Impact of Land Use Change on Hydrology by Ensemble Modeling (LUCHEM) III: Scenario analysis. Advances in Water Resources, 32(2): 159-170.

38. Hunt, E.D., K.G.Hubbard, D.A.Wilhite, T.J.Arkebauer \& A.L.Dutcher. 2009. The Development and Evaluation of A Soil Moisture Index. International Journal of Climatology, 29(5): 747-759.

39. Huntington,T.G. 2010. Climate Warming-Induced Intensification of the Hydrologic Cycle: An Assessment of the Published Record \& Potential Impacts on Agriculture. Advances in Agronomy, 109: 1-53.

40. IPCC. 2013. Climate Change 2013: The Physical Science Basis. Contribution of Working Group I to the Fifth Assessment Report of the Intergovernmental Panel on Climate Change Cambridge University Press, Cambridge, United Kingdom and New York, NY, USA.

41. IPCC. 2014. Climate Change 2014: Synthesis Report. Contribution of Working Groups I, II and III to the Fifth Assessment Report of the Intergovernmental Panel on Climate Change [Core Writing Team, R.K. Pachauri and L.A. Meyer (eds.)]. IPCC, Geneva, Switzerland, $151 \mathrm{pp}$.

42. Jain,S.K. \& V.Kumar. 2012. Trend Analysis of Rainfall and Temperature Data for India. Current Science, (102): 37-49.

43. Jenifa, L.C., S.Saravanan \& K.Palanichamy. 2010. A Semi - Distributed Water Balance Model For Amaravathi River Basin Using Remote Sensing And GIS. International Journal Of Geomatics And Geosciences, 1(2): 252-263.

44. Kirby,J.M., M. Mainuddin, F. Mpelasoka, M.D. Ahmad, W. Palash, M.E. Quadir, S.M. Shah-Newaz, \& M.M. Hossain. 2016. The Impact of Climate Change on Regional Water Balances in Bangladesh. Clim. Change, 135 (3): 481-491.

45. Las, I., Agus, F., Nursyamsi, D., Husen, E., Sutriadi, T., Wiratno., Syahbuddin, H., Jamil, A., Ritung, S., Mulyani, A., Hendrayana, R., Dariah, A., Suryani, E., Sulaeman, Y., Nurida, N.L., \& Rejekiningrum, P. 2014. Road Map Penelitian dan Pengembangan Lahan Kering. Balai Besar Penelitian dan Pengembangan Sumberdaya Lahan Pertanian. Badan Penelitian dan Pengembangan Pertanian. Kementerian Pertanian. ISBN 978-602-1280-76-8.

46. Lassa, J.A. 2012. Emerging Agricultural Involution in Indonesia: Impact of Natural Hazards and Climate Extremes on Agricultural Crops and Food System. In: Sawada, Y. 
and S. Oum (eds.), Economic and Welfare Impacts of Disasters in East Asia and Policy Responses. ERIA Research Project Report 2011-8, Jakarta: ERIA. pp.601-640.

47. Leng,G., Q.Tang \& S.Rayburg. 2015. Climate Change Impacts on Meteorological, Agricultural and Hydrological Droughts in China. Global and Planetary Change, 126: 2334.

48. Lennon,J.J. 2015. Potential Impacts of Climate Change on Agriculture and Food Safety within the Island of Ireland. Trends in Food Science \& Technology, 44(1): 1-10.

49. Loo,Y.Y., L.Billa \& A.Singh. 2015. Effect of Climate Change on Seasonal Monsoon in Asia and its Impact on The Variability of Monsoon Rainfall in Southeast Asia. Geoscience Frontiers, 6(9): 817- 823.

50. Machiwal, D., S.Kumar \& D.Dayal. 2016. Characterizing rainfall of hot arid region by using time-series modeling and sustainability approaches: A case study from Gujarat, India. Theor. Appl. Climatology, 124: 593-607.

51. Małgorzata, S. 2015. The Elements of Water Balance in the Changing Climate in Poland. Advances in Meteorology. Volume 2015, Article ID 149674, 13 pages. http://dx.doi.org/10.1155/2015/149674.

52. Mall,R.K., A.Gupta, R.Singh, R.S.Singh \& L.S.Rathore. 2006. Water resources and climate change: An Indian perspective. Current Science, 90: 1610-1626.

53. Mardawilis, P. Sudira., B.H. Sunarminto, \& D. Shiddiq. 2011. Analisis Neraca Air untuk Pengembangan Tanaman Pangan pada Kondisi Iklim yang Berbeda. Jurnal Agritech. 31(2): 109-115. (in Indonesian).

54. Mehta, V.K., V.R.Haden, B.A.Joyce, D.R.Purkey, \& L.E.Jackson. 2013. Irrigation Demand and Supply, Given Projections of Climate and Land-Use Change, in Yolo County, California. Agric. Water Manag., 117: 70-82.

55. Mo,X.-G., S.Hu; Z.-H.Lin, S.-X.Liu \& J.Xia. 2017.Impacts of Climate Change on Agricultural Water Resources and Adaptation on the North China Plain. Advances in Climate Change Research, 8(2): 93-98.

56. Mostajeran,A. \& V. Rahimi-Eichi. 2009. Effects of Drought Stress on Growth and Yield of Rice (Oryza sativa L.) Cultivars and Accumulation of Proline and Soluble Sugars in Sheath and Blades of Their Different Ages Leaves. American-Eurasian J. Agric. \& Environ. Sci., 5(2): 264-272, 2009.

57. Muchuru, S., J.O.Botai, C.M.Botai, W.A.Landman, \& A.M.Adeola. 2016. Variability of rainfall over Lake Kariba catchment area in the Zambezi river basin, Zimbabwe. Theor. Appl. Climatol., 124: 325-338.

58. Nzoiwu,C.P., E.I.Agulue, S.Mbah \& C.P.Igboanugo. 2017. Impact of Land Use/Land Cover Change on Surface Temperature Condition of Awka Town, Nigeria. Journal of Geographic Information System, 9: 763-776.

59. Ochieng,J., L.Kirimi \& M.Mathenge. 2016. Effects of Climate Variability and Change on Agricultural Production: The Case of Small Scale Farmers in Kenya. NJAS Wageningen Journal of Life Sciences, 77: 71-78.

60. Okonya,J.S., K. Syndikus \& J.Kroschel. 2013. Farmers' Perception of and Coping Strategies to Climate Change: Evidence From Six Agro-Ecological Zones of Uganda. Journal of Agricultural Science, 5(8): 252-263.

61. Palanog,A.D., B.P.M.Swamy, N.A.A.Shamsudin, S.Dixit, J.E.Hernandez, T.H.Boromeo, P.C.Sta.Cruz \& A.Kumar. 2014. Grain yield QTLs with Consistent-Effect Under Reproductive-Stage Drought Stress in Rice. Field Crops Research, 161: 46-54.

62. Pandey,V. \& A.Shukla. 2015. Acclimation and Tolerance Strategies of Rice under Drought Stress. Rice Science, 22(4): 147-161.

63. Patanè,C., S.Tringali \& O.Sortino. 2011. Effects of Deficit Irrigation on Biomass, Yield, Water Productivity and Fruit Quality of Processing Tomato Under Semi-arid mediterranean climate conditions. Sci. Horticulture, 129: 590-596.

64. Pedro,V., M.de Carvalhob, R.Serralheirob, R.Maiac, V. Ramosa, \& B.Oliveira. 2015. Climate change impacts on rainfed agriculture in the Guadiana Riverbasin (Portugal). Agricultural Water Management , 152: 17-30. 
65. Pereira, L.S. 2011. Challenges on Water Resources Management When Searching for Sustainable Adaptation to Climate Change Focusing Agriculture. Eur. Water, 34: 41-54.

66. Pravalie,R., I.Sirodoev, C.V.Patriche, G.Bandoc \& D.Peptenatu. 2014b. The Analysis of the Relationship Between Climatic Water Deficit and Corn Agricultural Productivity in the Dobrogea Plateau. Carpathian Journal of Earth and Environmental Sciences, 9(4): 201214.

67. Prijono, S. 2017. Neraca Air sebagai Landasan Pengembangan dan Manajemen Pertanian Berkelanjutan di Lahan Tadah Hujan. Pidato Pengukuhan Jabatan Guru Besar dalam Bidang IImu Hidrologi Pertanian pada Fakultas Pertanian Universitas Brawijaya. Disampaikan pada Rapat Terbuka Senat UB Malang, 10 Mei 2017.

68. Qu,W., H.R.Bogena, J.A.Huisman, M.Schmidt, R.Kunkel, A.Weuthen, H.Schiedung, B.Schilling, J.Sorg \& H.Vereecken. 2016. The Integrated Water Balance and Soil Data Set of The Rollesbroich Hydrological Observatory. Earth Syst. Sci. Data, 8: 517-529.

69. Rana,A., K.Foster, T.Bosshard, J.Olsson \& L.Bengtsson. 2014. Impact of climate change on Rainfall Over Mumbai Using Distribution-Based Scaling of Global Climate Model projections. Journal of Hydrology: Regional Studies, 1: 107-128

70. Reuter,M., A.K.Kern, M.Harzhauser, A.Kroh \& W.E.Piller. 2013. Global Warming and South Indian Monsoon Rainfall-Lessons from the Mid-Miocene. Gondwana Research, 23(3): 1172-1177.

71. Saadi,S., M.Todorovic, L.Tanasijevic, L.S.Pereira, C.Pizzigalli \& P.Lionello. 2015. Climate change and Mediterranean agriculture: Impacts on Winter Wheat and Tomato Crop Evapotranspiration, Irrigation Requirements and Yield. Agric. Water Manag., 147: 103-115.

72. Shaxson, F. \& R. Barber. 2003. Optimizing Soil Moisture for Plant Production. FAO Soils Bull. 79. http://www.fao.org/DOCREP/006/ Y4690E00.HTM.

73. Shipitalo,M.J., W.M.Edwards, W.A.Dick \& L.B. Owens. 1990. Initial Storm Effects on Macropore Transport of Surface-Applied Chemicals in No-Till Soil. Soil Sci. Soc. Am. J., 54: $1530-1536$.

74. Singh,C.M., B.Kumar, S.Mehandi \& K.Chandra. 2012. Effect of Drought Stress in Rice: A Review on Morphological and Physiological Characteristics. Trends in Biosciences, 5(4): 261-265.

75. Soemarno. 2011. Green Technology in Managing the Critical Drylands. Pengelolaan Lahan Kering dan Kritis. Post-graduate Program, Univ. of Brawijaya. Malang-Indonesia. ISBN 978-602-8624-38-1A. (in Indonesian).

76. Sugita, F., T.Kishii, \& M. English. 2004. Effects of Macropore Flow on Solute Transport in A Vadose Zone Under Repetitive Rainfall Events. Proceedings of Groundwater Quality 2004, the 4th International Groundwater Quality Conference, held at Waterloo, Canada, July 2004.

77. Sujalu,A.P., S.Ismali, C.B.Hardiwinarto \& Sumaryono, 2014. Analysis of Water Balance for Determining Cropping Pattern for Food Crops in Watershed Karangmumus the Province of East Kalimantan. AgroLife Scientific J., 3: 2-xx.

78. Sukerta,I.M., S.Prijono, R.Soelistyono \& Soemarno. 2013. Soil Moisture Balance in The Root Zone Under Different Cropping Systems at Pecatu Village, Bali-Indonesia. J. Basic. Appl. Sci. Res., 3(7): 920-927.

79. Sultana, S.N., U.M.Hazarika, \& U.K.Misra. 2017. Improvement of Water Use Efficiency and Remote Sensing Applications for Surface Soil Moisture Monitoring. ADBU-J. Eng. Technol. Sult., 6: 2348-7305.

80. Surmaini, E., T.W. Hadi, K. Subagyono, \& N.T. Puspito. 2015. Early Detection of Drought Impact on Rice Paddies in Indonesia. Theoretical and Applied Climatology, 121: 669684.

81. Suryadi, Y., D.N.Sugianto, \& Hadiyanto. 2017. Identifikasi Perubahan Suhu dan Curah Hujan serta Proyeksinya di Kota Semarang. Proceeding Biology Education Conference, 14(1): 241- 246. 
82. Thornthwaite, C.W. \& J. R. Mather. 1957. Instruction And Tables For Computing Potensial Evapaotranspiration And Water Balanced. Publ. In. Clim. Vol X. No.3. Centerton, New Jersey.

83. Thuy, P.T., M. Moeliono, B. Locatelli, M. Brockhaus, M.D. Gregorio, \& S. Mardiah. 2014. Integration of Adaptation and Mitigation in Climate Change and Forest Policies in Indonesia and Vietnam. Forests, 5(8): 2016-2036.

84. Trenberth, K.E., A.Dai, G.Van Der Schrier, P.D.Jones, J.Barichivich, K.R.Briffa \& J.Sheffield. 2014. Global Warming and Changes in Drought. Nat. Clim. Chang., 4: 17-22.

85. Tufaila,M., L.Mpia \& J.Karim . 2017. Analisis Neraca Air Lahan pada Jenis Tanah yang Berkembang pada Daerah Karts di Kecamatan Parigi Kabupaten Muna Sulawesi Tenggara. AGRITECH, 37(2): 215-219.

86. Wahjunie,E.D., O.Haridjaja, H.Soedodo \& Sudarsono. Pergerakan Air pada Tanah dengan Karakteristik Pori Berbeda dan Pengaruhnya pada Ketersediaan Air bagi Tanaman. Jurnal Tanah dan Iklim No. 28/2008. ISSN 1410 - 7244.

87. Wang,K., R.E. Dickinson \& S. Liang. 2012. Global atmospheric Evaporative Demand Over Land From 1973 to 2008. J. Clim., 25: 8353-8361.

88. Wang,X., W. Lu, Y.J.Xu, G.Zhang, W.Qu \& W.Cheng. 2016. The Positive Impacts of Irrigation Schedules on Rice Yield and Water Consumption: synergies in Jilin Province, Northeast China. International Journal of Agricultural Sustainability. 14(1): 1-12.

89. Wang,X.J., J.Y.Zhang, M.Ali, S.Shahid, R.M.He, X.H.Xia \& Z.Jiang. 2016. Impact of Climate Change on Regional Irrigation Water Demand in Baojixia Irrigation District of China. Mitig. Adapt. Strateg. Global Change, 21: 233-247.

90. Wanga,J., R.Ghimirec, X.Fua, U.M.Sainjud \& W.Liue. 2018. Straw Mulching Increases Precipitation Storage Rather Than Water Use Efficiency and Dryland Winter Wheat Yield. Agric.Water Management, 206:95-101.

91. Winarto,Y.T., K.Stigter, B.Dwisatrio, M.Nurhaga \& A.Bowolaksono. 2013. Agrometeorological Learning Increasing Farmers' Knowledge in Coping With Climate Change and Unusual Risks. Southeast Asian Studies, 2(2): 323-349.

92. Wu,N.,Y.Guan \& Y.Shi. 2011. Effect of Water Stress on Physiological Traits and Yield In Rice Backcross Lines after Anthesis. Energy Procedia, 5: 255-260.

93. Xu,M., B.S.Ye, Q.D.Zhao, S.Q.Zhang \& J.Wang. 2013. Estimation of water balance in the source region of the Yellow River based on GRACE satellite data. J. Arid Land, 5(3): 384-395.

94. Xu,Y., C. Xu, X.Gao \& Y.Luo. 2009. Projected Changes in Temperature and Precipitation Extremes Over the Yangtze River Basin of China in the 21st century. Quatern. Int., 208: 44-52.

95. Zangiabadi,M., M.Gorji, M.Shorafa, S.K.Khorasani \& S.Saadat. 2017. Effects of Soil Pore Size Distribution on Plant Available Water and Least Limiting Water Range as Soil Physical Quality Indicators. Pedosphere (2017), 10.1016/S1002-0160(17)60473-9

96. Zhao, L. \& W.Zhao. 2014. Evapotranspiration of an Oasis-Desert Transition Zone in the Middle Stream of Heihe River, Northwest China. Journal of Arid Land, 6(5): 529-539.

97. Zhao,W., B.Liu \& Z. Zhang. 2010. Water requirements of Maize in the Middle Heine River basin, China. Agricultural Water Management, 97(2): 215-223.

98. Zhou,T., P.Wu, S.Sun, X.Li, Y.Wang \& X.Luan. 2017. Impact of Future Climate Change on Regional Crop Water Requirement-A Case Study of Hetao Irrigation District, China. Water, 9(429): 1-13.

99. Zubaidah, A. 2012. Analisis Perubahan Curah Hujan Satelit Tropical Measuring Mission (TRMM) Tahun 2009 dan Tahun 2010. Widya, 29(320). 